IZA DP No. 9936

Who Wins? Evaluating the Impact of UK Public Sector Pension Scheme Reforms

Alexander Danzer

Peter Dolton

Chiara Rosazza Bondibene

May 2016 


\title{
Who Wins? Evaluating the Impact of UK Public Sector Pension Scheme Reforms
}

\author{
Alexander Danzer \\ Catholic University of Eichstätt-Ingolstadt, \\ IZA and CESifo \\ Peter Dolton \\ University of Sussex, \\ CEP, LSE and IZA
}

\section{Chiara Rosazza Bondibene NIESR}

\author{
Discussion Paper No. 9936 \\ May 2016
}

IZA
P.O. Box 7240
53072 Bonn
Germany

Phone: +49-228-3894-0

Fax: +49-228-3894-180

E-mail: iza@iza.org

\begin{abstract}
Any opinions expressed here are those of the author(s) and not those of IZA. Research published in this series may include views on policy, but the institute itself takes no institutional policy positions. The IZA research network is committed to the IZA Guiding Principles of Research Integrity.

The Institute for the Study of Labor (IZA) in Bonn is a local and virtual international research center and a place of communication between science, politics and business. IZA is an independent nonprofit organization supported by Deutsche Post Foundation. The center is associated with the University of Bonn and offers a stimulating research environment through its international network, workshops and conferences, data service, project support, research visits and doctoral program. IZA engages in (i) original and internationally competitive research in all fields of labor economics, (ii) development of policy concepts, and (iii) dissemination of research results and concepts to the interested public.
\end{abstract}

IZA Discussion Papers often represent preliminary work and are circulated to encourage discussion. Citation of such a paper should account for its provisional character. A revised version may be available directly from the author. 


\section{ABSTRACT \\ Who Wins? Evaluating the Impact of UK Public Sector Pension Scheme Reforms ${ }^{1}$}

Radical changes have been implemented to pension schemes across the UK public sector from April 2015. This paper simulates how these changes will affect the lifetime pension and how the negotiated pension changes compare across six public sector schemes by level of education. Specifically, we simulate the occupation specific Defined Benefit (DB) pension wealth accumulated for a representative employee over the lifecycle by factoring in the recent changes to pension conditions. We find that less educated workers with low or moderate earnings in the NHS, Local Government and Civil Service schemes are the winners having secured an increase in the value of their pension of between 10-20\%. Graduate workers with faster wage growth in the Civil Service, Teachers and Local Government schemes loose between $3 \%$ and $5 \%$. This is in sharp contrast with the Police and Fire forces who have lost around $40 \%$ irrespective of their education.

JEL Classification: J32, H55, J45

Keywords: $\quad$ pension reforms, public sector, defined benefit

Corresponding author:

Chiara Rosazza Bondibene

National Institute of Economic and Social Research

2 Dean Trench Street, Smith Square

London SW1P 3HE

United Kingdom

E-mail: c.rosazza bondibene@niesr.ac.uk

\footnotetext{
${ }^{1}$ Disclaimer: This work contains statistical data, which is Crown Copyright; it has been made available by the Office for National Statistics (ONS) through the Secure Data Service (SDS) and has been used by permission. Neither the ONS nor SDS bear any responsibility for the analysis or interpretation of the data reported here. This work uses research datasets, which may not exactly reproduce National Statistics aggregates.
}

Acknowledgements: The financial support of the Economic and Social Research Council grant reference ES/L014920 is gratefully acknowledged. We would like to thank Matt Dickson, Richard Disney, Katerina Lisenkova, John Ralfe, Steven Taylor, lan Tonks, Lucy Stokes and participants to the conference on the Future of Pension at NIESR for useful comments. Guidance received from Margaret McEvoy and her colleagues at the Office of Manpower Economics, BIS is also acknowledged although OME takes no responsibility for the contents of this paper and it may not represent the views of OME or BIS. 


\section{Introduction}

The Great Recession in the world economy from 2008-14 has accelerated the need for pension reform across many countries, the UK included (Burtless 2010). The present UK government and the previous Coalition government have seen public sector pensions as being one of the most important contributory factors in the crisis of government's fiscal position. The Public Sector Net Cash Requirement (PSNCR) brought benefit entitlements and contribution rates under scrutiny, as unsustainable levels of public debt are cut back. As a result, radical changes have been implemented to pension schemes across the public sector from April 2015. Following the Independent Public Service Pensions Commission Final Report in the UK chaired by Lord Hutton (2011), the reforms of 2015 affected the computation of public pension entitlements fundamentally. This will impact the future incomes of all public sector staff, even those who enrolled into established public sector pension schemes with more generous parameters (except for those within ten years of their National Pension Age).

Rising life expectancy ${ }^{2}$ is a major factor in the need for pension reform as it means that public service pensions are paid longer to each retiree than envisaged when the schemes were designed. As a result, more expensive pensions have to be predominantly borne by taxpayers (HM Treasury, 2011). This is especially true for the unfunded pension schemes that are typical in the public sector ${ }^{3}$. Longer life expectancies could only be balanced: by working longer, by higher pension contributions or by lower pension benefits in retirement. While the UK has experienced a long history of public sector pension reforms (Disney, Emmerson and Wakefield 2008), the 2015 changes are more fundamental than previous reforms.

Concomitant with the scrutiny of pension payments has been a more wide ranging policy discussion of the 'Total Reward' on offer in each public sector remuneration package. Each of the public sector pay review bodies have been placing more emphasis on the comparison of public sector pay in any given occupation with that on offer in comparable private sector counterparts. This scrutiny has included the value of pension benefits and other conditions of employment. This need for a Total Reward methodology was the challenge taken up in Danzer and Dolton (2012) who compared the whole public sector with the whole

\footnotetext{
${ }^{2}$ See for example: http://www.ons.gov.uk/ons/dcp171778_426798.pdf.

${ }^{3}$ Most of UK public sector pension schemes we consider are 'unfunded', in that the pension benefits are not underpinned by a fund and they are paid directly from current workers' contributions and central government taxation. This position contributes to the the fiscal problems faced by the UK government. One exception is the 'funded' Local Government Pension scheme, in which the pot of money that individuals have on retirement is determined by the contributions paid into the scheme, after charges, from investing these contributions in pension funds and from Local Government Revenue (for example Council Tax) (PPI, 2005).
} 
private sector, in terms of lifetime earnings and pensions and the whole remuneration package. Now public policy focus has turned to individual pension arrangements in the separate public sector occupations in the light of recent reforms. In this contribution, we examine into the pension component of Danzer and Dolton's (2012) simulation approach to perform a detailed analysis of the value of each occupation's pension under the old system - before the reforms of 2015 - to compare it with what has now been implemented.

The public sector pension schemes we focus our attention on are: the NHS (England and Wales); the Civil Service (UK); Teachers (England and Wales); Local Government (England and Wales); Police (England) and Fire Services (England and Wales). All these schemes experienced changes from April 2015, with the exception of the Local Government Pension Scheme, which introduced the changes in 2014. While different schemes remain for different sectors, the reforms have similarities across groups:

- Importantly, the DB structure of public sector pensions has been maintained, but the pension benefit is now linked to the Career Average Revalued Earnings (CARE), rather than the scheme member's final salary. One important reason for introducing a CARE scheme was to address the unfairness typical of a final salary setting, where workers who experience faster wage growth (such as the more educated) benefit at the expense of staff with low or moderate earnings (Independent Public Service Pensions Commission, 2011). However, this also implies less back-loading of pensions with potentially negative implications for staff retention at older ages, especially of high-flyers (Ippolito 1985; Disney 1995). Also, those who tend to take lower wages at the very end of their career (reducing hours and perhaps stepping down from the higher-pressure executive roles) might decide to retire earlier under a CARE system in order not to drag down their average wage.

- The Normal Pension Age (NPA) in public service schemes has been aligned with the higher State Pension Age (SPA). There are exceptions to this: the NPA was set to 60 for the uniformed forces such as Police and Fire Service to reflect the unique characteristics of their work (Independent Public Service Pensions Commission, 2011).

- The average member contributions are increased.

The proposed reforms apply to all members; however, members within ten years of their NPA on 1 April 2012 will have their pension calculated according to the rules in place prior the introduction of the proposed reforms.

The main differences between the schemes include the rate of accrual, the revaluation of active member benefits and the rate of member contributions. These decisions were set by agreement in negotiations between the public sector unions, and the relevant government departments in conjunction with the HMTreasury. 
These negotiations determined how the precise parameters of each public sector schemes have changed in 2015. Most changes to the pension parameters in 2015 resulted in a decrease of benefit levels. To counterbalance some of the resulting deterioration of pensions, most schemes saw their accrual rates increase (with the exception of police and fire fighter schemes).

The permanent reduction in pension generosity will have lasting and sizeable effects on the total lifetime remuneration of affected cohorts of workers. Yet, the reforms will affect public sector employees of both sexes differently, as for instance, the effect of switching from final salary to career average Defined Benefit (DB) schemes will depend on the steepness of the particular age-earnings profiles. Moreover, the different public sector pension schemes face heterogeneous change (e.g. in indexation, contributions etc.) which complicate the assessment of the financial consequences. These differences are summarized in Table 1. How will the proposed pension changes affect the lifetime pension wealth across the public sector by education and which pension occupational schemes will be most affected?

This paper answers these questions combining the definition of DB pension wealth accumulated over the lifecycle with a simulation methodology that assesses the implemented changes to the pension parameter settings. In contrast to most previous research on pension wealth (Disney et al. 2009; Crawford et al. 2010; a notable exception is Disney and Whitehouse 1996) we take a lifecycle perspective which is different from analyses that examine aggregate average changes to pension wealth within a sector (PPI 2013); our approach allows comparing the accumulated lifetime pension wealth at every point in a worker's career. The methodology for computing the net present value (NPV) of pension accruals over the lifecycle can be applied to examine how public sector employees differ across the entire life cycle and may inform us about how changes to specific pension parameters affect their relative position.

The purpose of this paper is to simulate the impact of these reforms and calculate which occupational pension scheme got the 'best deal'. We repeat our analysis by broad education level (Bardasi and Jenkins 2010). Our paper contributes to the literature in the following way: First, we simulate the impact of all implemented pension changes on the accumulated pension wealth of public sector employees following the 2015 reforms. We also include the impact of the reform already implemented in 2011 by the Coalition Government, which changed the inflation indexation of pension payments from the Retail Price Index (RPI) to the Consumer Prices Index (CPI). Second, we simulate the accumulated pension wealth over the entire life cycle. Third, we provide the first comparative assessment of pension wealth across different public sector occupations. To do this we use the concept of a representative worker because we wish to make comparisons of the 
variability of the new pension conditions in each occupation - hence it is most appropriate to do this using an average 'representative' public sector worker with the average life time earnings profile - rather than to confound the reform impact with differences in age-earnings profiles across occupations. In this way we are keeping the age-earnings profile for the worker (by gender and education) constant and only changing the pension conditions in each occupation. This approach allows us to determine consistently which occupational pension scheme has bargained the smallest loss (or greatest gain) to its members' pension wealth.

The paper is organized as follows. Section 2 outlines our computational methodology. Section 3 describes the data sources we use in our analysis. The results are presented in section 4 . Finally, section 5 concludes and provides a brief outline of the possible implications of our findings.

\section{Methodology}

The asset value of a DB pension is evaluated as the sum of the discounted DB benefit stream from retirement until death. For this computation, knowledge about retirement dates and the remaining life expectancy at retirement is required. The actual benefit value will depend on the pension plan details provided by different employers (i.e. accrual rates, accrual base, NPA, initial vesting period, lump sum options, survivors' benefits, and indexation) as well as specific employee details like levels of past earnings and number of years in service.

The data requirements to calculate the DB level for the average public sector pensioner are high. Ideally, they would require us to know all of the lifetime earnings for the individual. We will need to assume that the life cycle earnings profile can be approximated by looking at the cross section age-earnings profile for the most recent cohorts for whom we have data. However, it should be understood that this is not the same as a true lifetime earnings profile. To exclusively focus on the wealth effect of the reform, we compute the DB pension wealth for the same representative public sector worker under the pre-2002 vs. the reformed pension schemes. ${ }^{4}$ The representative worker has identical earnings and working hours across occupations, only differentiated by gender and educational group (A-level and below vs. above A-level).

\footnotetext{
${ }^{4}$ Some of the scheme members affected by the changes of the 2015 reforms may have seen the implementation of other adjustments since 2002-like changes to indexation or ill health rules, the closure of specific contracts to new entrants or the abolition of lump sum at retirement, except through a concomitant reduction in pension. To make the base year of the 'old scheme' comparable across occupations we have chosen the year 2002 as benchmark when comparing the 2015 changes. Since the implemented changes of the 2000s were minor, we are de facto comparing the post 2015 pension position with the pre-2015 pension position in each occupation. For a detailed description of occupational pensions prior to 2002 see Blake 2003, chapter 6. For an analysis of one of the post 2002 reforms see Crawford and Disney (2014).
} 
Assuming a person is for their entire working life in a pre-2002 DB pension scheme $i$, which is based on terminal salary $\left(w_{T i}\right)$, value at time $\mathrm{T}$ then the accumulated value of such a pension at pension age $r$ is :

$$
D B_{r i}^{\text {old }}=\sum_{r=1}^{D_{1 i}} \delta^{r} \sigma^{R P I} \gamma_{i} \ell_{i} w_{T i}+\sum_{s=1}^{D_{2 i}} \theta_{i} \delta^{S} \sigma^{R P I} \gamma_{i} \ell_{i} w_{T i}+\delta^{r} \beta_{i} \gamma_{i} w_{T i}
$$

where subscripts $i$ denotes the different public sector pension schemes we are focusing on (i.e. NHS, Teachers, Civil Service, Local Government, Police and Fire Services). $D_{1 i}$ is the person's year of death in scheme $i, D_{2 i}$ is the partner's year of death in pension scheme $i, \delta$ is the discount rate $(2 \%)^{5}, \sigma$ is the inflation revaluation of pension in payment (which is RPI in the old schemes and CPI in the new schemes $\left.{ }^{6}\right), \gamma$ is the cumulated years in the scheme in occupation $i, \ell$ is the loading of the scheme in occupation $i, \theta_{i}$ is the fraction for survivor pension (paid from death of the pensioner at time $s$ until the partner's death) and the last term in equation (1) is the lump sum paid in most DB schemes before 2002, where $\beta$ is the lump sum fraction in scheme $i$. Since the lump sum was tax-free, we apply a re-grossed value assuming a 20\% income tax rate (as in Danzer and Dolton 2012). It should be noted that the terminal salary is the best out of the previous three years, which is the standard rule in most DB schemes.

Assuming instead a person is for their entire working life in a 2015 reformed pension scheme $i$, which is now based on career average salary $\bar{w}_{i}$, then the accumulated value of such pension at pension age $r$ is:

$$
\widehat{D B}_{r i}^{\text {new }}=\sum_{r=1}^{D_{1 i}} \delta^{r} \sigma^{C P I} \gamma_{i} \ell_{i} \mu_{i} \bar{w}_{i}+\sum_{s=1}^{D_{2 i}} \theta_{i} \delta^{s} \sigma^{C P I} \gamma_{i} \ell_{i} \mu_{i} \bar{w}_{i}
$$

An important aspect to note is that DB pension wealth in equation (2) is no longer a final salary scheme, based on the salary at the end of the career $w_{T i}$, but it is a CARE pension scheme based on the average salary $\bar{w}_{i}$ (an average of the salaries received in each year of work and revaluated by $\left.\mu_{i}{ }^{7}\right) . \mu_{i}$ is the revaluation of active member benefits reported in Table 1 which varies across pension schemes.

\footnotetext{
${ }^{5}$ For a discussion on discount rates see Danzer and Dolton (2012).

${ }^{6}$ The CPI is typically lower than RPI because it uses the geometric mean of prices whereas the latter uses the arithmetic mean. As the geometric mean is less or equal to the arithmetic, the CPI can at best be the same as the RPI but it is almost always lower than it. Also the CPI excludes housing costs.

7 To calculate the pension in a CARE scheme, an employee's earnings during each year of his employment are taken into account and averaged. In order to maintain the value of pension earned each year, annual earnings are revalued up to the time of retirement before being averaged.
} 
The idea of the paper is to simulate the impact of the various public sector pension reforms. We do this by comparing the NPV of accumulated lifetime DB pension wealth in the pre-2002 pension schemes $\sum_{v}^{\tau} \delta^{(\tau-v)} D B_{r i}^{o l d}$ with the one of the schemes introduced in $2015, \sum_{v}^{\tau} \delta^{(\tau-v)} \widehat{D B}_{r i}^{\text {new }}$. Hence, at each given age $\tau$ we evaluate the DB wealth as if this was the first year of pension withdrawal, discounting back to the career start at age $v$. The DB pension (dis-)advantage of the 2015 scheme over the 2002 scheme for each occupation $i$ can be calculated from:

$$
P A_{r i}^{\text {new }}=\frac{\sum_{v}^{\tau} \delta^{(\tau-v)} \widehat{D B}_{r i}^{\text {new }}-\sum_{v}^{\tau} \delta^{(\tau-v)} D B_{r i}^{o l d}}{\sum_{v}^{\tau} \delta^{(\tau-v)} D B_{r i}^{o l d}}
$$

Negative values of $P A_{r i}^{\text {new }}$ reflect a deterioration of the NPV of accumulated pension wealth under the reform.

\section{Data}

A careful comparison of DB pension schemes requires accurate information on age-earnings profiles, pension scheme membership as well as pension scheme parameters. Our computation will be based on the same underlying gender-specific data on age-earnings profiles for a representative public sector full time worker either with education above A-level aged 22 to 59 or with low education (A-level or below) aged 20 to 59 .

For the estimation of age-earnings profiles, we use the Annual Survey of Hours and Earnings (ASHE). It is based on a 1 per cent sample of employees' jobs taken from PAYE records of HM Revenue \& Customs. ASHE is a large-scale survey and is regarded as the most reliable source of earnings in the UK and it is available from 1997 to 2013. Earnings of public sector employees are taken as hourly pay data from the ASHE. We follow Disney et al. (2009) in estimating these profiles net of sector-specific average earnings growth and in real terms (2013 gross values). For consistency reasons, we use ASHE employer-reported working hours in our analysis.

Figure 1 reports the median age-earning profiles by level of education. In the absence of information on workers' qualifications in the ASHE, we evaluate the average skill content of individual occupations for difference age groups using the Labour Force Survey (LFS) and map the age-specific education-occupation matrix 
into the data ${ }^{8}$. As expected, an average educated public sector worker earns more at each age than a less educated one.

Crucial data for the computation of DB pension wealth are pension membership and scheme parameters across occupations. The ASHE data provides information on membership in a range of occupational pensions. With this information it is possible to distinguish between public sector workers by age and gender and education under a DB scheme. Scheme parameters as of 2002 (prereform) and 2015 (post reform) are collected from publicly available reports (PPI, 2015 and official occupational public sector pension guides) and are reported in detail in Table 1 . We assume there are differences in longevity of public sector workers. Life expectancies are gender specific cohort values and depend on occupation and social class ${ }^{9}$.

We do not make any specific assumptions about job and pension scheme tenure, but assume that individuals remain a member of the old or reformed pension scheme throughout their entire active working life. For this reason, we ignore that the current reforms affect some workers differently depending on their age and service years in the old scheme. In particular we ignore those under tapered protection (which will remain under old pension scheme conditions for a period of time after April 2015 and then move to the new reformed schemes on a transition date) and transition members (all existing members of the old schemes that will move to the new reformed schemes on 1 April 2015). In addition, recent employees (employed from 2002 to 2008 depending on the pension scheme) tend to be in different schemes to those with longer service. For most this remains a final salary scheme, but with changes in accrual rates and later retirement ages. For the sake of simplicity in this paper, we also ignore minor changes in pension scheme conditions between 2002 and 2008.

Due to the complexities of the UK pension system, we have to make some further simplifying assumptions in order to perform our calculations of work related pensions. DB pension holders are assumed to draw their pensions at the

\footnotetext{
8 We use the matrix developed by Dolton, Makepeace and Marcerano-Gutierrez (2014). They base their grouping of occupations on UK Standard Occupational Classification. We update their analysis to take into account the change in UK occupational classifications between SOC2000 and SOC10 in ASHE in 2011.

${ }^{9}$ We use ONS gender-specific life expectancies upon reaching age 65 for analytic classes and occupations for period 2002-2006.

https: / $/$ www.google.de/url?sa=t\&rct=j\&q=\&esrc=s\&source=web\&cd=1\&cad=rja\&uact=8\&ved=0CCI QFjAAahUKEwiM6biXlY3HAhVmcHIKHR8ECuU\&url=http\%3A\%2F\%2Fwww.ons.gov.uk\%2Fons\%2F guide-method $\% 2$ Fclassifications $\% 2$ Fcurrent-standard-classifications $\% 2$ Fsoc $2010 \% 2 \mathrm{Fns}$-sec- 2010 derivationtables.xls\&ei=RIC VYy3AubgyQOfiKioDg\&usg=AFQjCNFfSyCayvTmsLKAvSPU psSVkDacQ\&bvm=bv.9 9261572,d.bGQ
} 
NPA as in Table 1. Survivor's benefits are only valued for males, as women live statistically longer than men do. A final caveat is the treatment of different kind of risks (for a detailed analysis on the pension context see Blake, 2006). Attitudes toward risk (risk aversion) and time preferences (discount factor) may differ across public sector occupations and age. Furthermore, the risk associated with being a member of a different DB scheme may differ. For this analysis, we are assuming constant discount rates across public sector occupations and ignoring differences in the other risk components.

\section{Results}

Our main analysis is done in two steps. ${ }^{10}$ First, we compute DB pension wealth assuming that in the 2015 schemes workers retire at NPA (for NHS, Teachers, Civil Service and Local Government schemes at age 65 and for Police and Fire Services at age 60). In the second step of the analysis, we compute DB pension wealth assuming that those in the 2015 schemes retire at the same age as those in the pre-2002 schemes (for NHS, Teachers, Civil Service at age 60, Police and Firefighters at age 55). We do this by simply taking the DB pension wealth in the 2015 schemes computed in the first step and multiplying it by the early retirement penalty factor ${ }^{11}$ for retiring 5 years before NPA as reported in Table 1 . This allows us to make a more consistent comparison between the old and newly introduced pension schemes.

Figures 2 and 3 show the proportionate changes in the relative value of DB pension wealth accumulated over the working life within each occupation scheme. The figures focus on our final set of results (i.e. the second step of analysis). Here we take into account of the fact that a worker under the old pension scheme retires 5 years earlier than someone under the 2015 reformed systems (except for the case of Local Government where retirement age is unchanged after the reforms). Our intermediate results (i.e. our first step of analysis) are reported in Figures A1 and A2 in the online Appendix. Figure 2 focuses on educated workers (above A-levels) and Figure 3 on less educated ones (A-level or below) ${ }^{12}$. The figures report an average of results for men and women (weighted by cell size) ${ }^{13}$. It is immediately clear from both figures that Fire and Police Services are made substantially worse off under the

\footnotetext{
${ }^{10}$ While reporting pension levels might seem interesting, we are reluctant to report them since our use of representative education specific agents will deliver absolute pension levels which do not necessarily reflect actual benefit levels in the professions.

${ }^{11}$ Early retirement factors are specific of each pension scheme and available online in each pension scheme's website.

${ }^{12}$ Since teaching has been an all graduate job (on entry) for over 30 years, we omit results for low educated teachers.

${ }^{13}$ Gender specific results can be obtained from the authors on request.
} 
new pension schemes; even if less educated workers are better off, the level of education does not seem to make a large difference in their case. The level of education, however, seems to matter more for the other public sector pension schemes. While graduate civil servants are losing out under the 2015 reforms, less educated workers seem to accumulate higher pension wealth in the new scheme in the last 5 years of their working life. Local Government workers are generally better off under the new scheme and definitely more so if low educated. Finally, less educated NHS employees seem to accumulate higher pension wealth over the career after the reforms. For graduate NHS workers, and similarly for teachers, this is only true at the start of the working life and when they reach pension age their economic position actually worsens under the new pension scheme.

Figure 4 summarizes our final results, showing the proportionate changes in the relative value of DB pension wealth accumulated when reaching NPA within each occupation scheme (exactly the last points of Figures 2 and 3 above). Police and Fire forces are certainly losing the most due to these reforms, with a decline of average accumulated pension wealth of around $40 \%$, with the low educated only slightly better off than those with above A-level qualifications. As mentioned above, education seems to matter more for the other pension schemes. Low educated Civil Servants and NHS workers are more than $10 \%$ and $20 \%$ better off under the new schemes, while educated Civil Service, NHS workers and teachers are losing around $5 \%, 1 \%$ and 3\%, respectively. Local Government employees stand out as those receiving the best deal: the 2015 reform increased the value of their pension by $40 \%$ if they are in the lower education and by $20 \%$ if they are in the graduate education level group. These results use the assumption that Local Government workers under the old scheme were retiring at their NPA, which was 65 . It should be pointed out, however, that members under the old scheme had an option to retire from age 60, without employer consent and actuarial reduction, if the sum of their age and their length of service equaled or exceeded 85 years (the so-called rule of 85, which was unique to the Local Government Pension Scheme). Even if many Local Government employees met the 85 -year rule ${ }^{14}$, it is not exactly clear how many of these workers were actually retiring earlier since they took the risk of having a lower pension wealth by contributing 5 working years less. Using ASHE longitudinal information on local government workers, we compute the proportions of employees who retire

${ }^{14}$ An information gathering programme found that almost $90 \%$ of the pensions of men and two thirds of the pensions of women would have been payable without reduction at 60 under the rule of 85 for members retiring between 2001 and 2004 (Thurley, 2009). 
between 60 and $65^{15}$ and we find that around 29\% retire at age 60 and $17 \%$ at age 65 (and the rest between 61 and 64). Under these assumptions, we calculate a revised proportionate change in the relative value of DB pension wealth for Local Government workers (labelled 'Loc.Gov. L' in Figure 4), finding that less educated employees are still around $20 \%$ better off under the new scheme. These results seem to be more in line with those of other pension schemes such as the NHS, Civil Service and Teachers.

Table 2 translates the proportionate changes in the relative value of occupational pensions schemes into monetary net present values over then entire retirement period. Graduate NHS workers will be around $£ 700$ worse off, graduate teachers around $£ 6700$, non-graduate police and firemen even $£ 79 \mathrm{k}$ and $£ 100 \mathrm{k}$ worse off respectively. In contrast, the average non-graduate local government employee will be around $€ 35 \mathrm{k}$ better off, if we assume they retire at 65 under the old scheme.

Fire and Police forces are the most penalized as we are de facto comparing the very generous pension schemes, respectively of 1992 and 1987 with the 2015 reformed one. These old schemes were offering a low NPA. They also had a unique feature: a two-tier accrual rate by which pension rights accrued at an annual rate of $1 / 60^{\text {th }}$ for the first 20 years, following by rights accrued at $1 / 30^{\text {th }}$ for each year thereafter, providing for a very rapid accrual of rights later in the career. Is should also be pointed out that the assumption behind the old pensions schemes for the Police and the Fire Service was they would typically retire from the job before 50 and would be most likely to have a second career.

An important final point to make is that the figures presented in this paper just evaluate the change in pension wealth among various employee groups after the current reforms. It is worth stressing that this does not necessarily imply that the level of pension wealth accumulated over the lifetime after the reform is lower for a Policeman or a Firefighter than for a Local Government officer. In fact, the change in pension wealth due to the reform has affected Police and Fire Services most.

\section{Discussion and conclusions}

Recent events mean that we all need to pay careful attention to what is happening to our pension, especially those in the public sector. Due to the size of the PSBR and the current recession, the current government and the previous coalition

\footnotetext{
${ }^{15}$ We assume that workers who exit the sample are retiring. We cannot control for those exiting the sample because they change jobs, but this is unlikely to happen at retirement age (i.e. between 60 and 65).
} 
government have chosen to cut the size of the public debt. These changes are predicated on the view that public sector pay and pensions have been allowed to rise too high in relative terms and that the burden of taxation to fund public sector pay and pension needs to be reduced. At the same time, due to increasing life expectancy there has been growing concern about the demographic balance of the population and the burden of the pension obligations to public sector workers in the future.

This paper defined and calculated what is meant by DB pension wealth accumulated over the lifetime for each public sector pension scheme and examined what the ratified changes to the pension system mean in various public sector schemes. The paper finds that public sector workers are, on average, worse off in the recently introduced pension schemes. However, the average masks substantial occupational variation: Those in the Local Government and NHS schemes are getting by far the best deals, Police and Fire Services are much worse off, while Teachers and those in Civil Service schemes are located somewhere in between the two extremes. We also disaggregated our analysis by the highly educated and those with lower educational qualifications. Educational background seems to matter, with higher educated workers (1) seeing a relative pension wealth loss under the reform and (2) being worse off than those with lower qualifications in all but the Local Government scheme. Differences in education are, at least in part, driven by the fact that educated workers have steeper earnings profiles and therefore tend to be more disadvantaged by a CARE pension scheme compared to a final salary one.

The implications of our findings are potentially wide-ranging and pose many important public policy questions. At the most basic level the Government has - to some extent - succeeded in improving the conditions of the less educated - but are these reforms affordable? As the time interval between the reforms and the withdrawal of their pension benefits is considerable, many policy questions of interest will have a long time dimension. Amongst them are: Was it fair to impose these pension changes on workers retrospectively when they actually entered these occupations under very different contractual conditions? Did the government mean there to be such a large redistribution of pension wealth away from such key workers as the Police, Firefighters and Teachers. Is the highly favourable pension position of the Local Government employees affordable? What will be the recruitment consequences for the potential future supply of young people into these occupations? Did the government consider potential problems in the retention of high fliers in the public sector at the end of their career? Will these adverse pension changes require appropriate adjustments in salaries of the affected workers to restore compensating pay differential? These are all questions that will inevitably 
have to be faced by future governments who need to recruit the right calibre of people into these key public sector occupations. 


\section{References}

Bardasi, E. and Jenkins, S. (2010). "The gender gap in private pensions", Bulletin of Economic Research, 62, 4: 343-363.

Barr, N and Diamond, P. (2008) 'Reforming Pensions: Principles and Policy Changes', Oxford. Oxford University Press.

Burtless, G. (2010) 'Lessons of the Financial crisis for the design of national pension systems', CESifo Economic Studies, 56(3):323-49.

Blake, D. (2003) 'Pension Schemes and Pension Funds in the United Kingdom', 2nd ed, Oxford, Oxford University Press.

Blake, D. (2006). “Pension Economics”. Pensions Institute, Wiley and Sons.

Crawford, R., Emmerson, C. and Tetlow, G. (2010). Occupational pension value in the public and private sectors. IFS Discussion Paper 10/03.

Crawford, R. and Disney, R. (2014). "Reform of police pensions in England and Wales", Journal of Public Economics, 116: 62-72

Danzer, A.M. and Dolton, P. (2012). "Total Reward and pensions in the UK in the public and private sectors", Labour Economics, 19: 584-594.

Disney, R. (1995). "Occupational Pension Schemes: Prospects and Reforms in the UK”, Fiscal Studies, 16(3): 19-39.

Disney, R., Emmerson, C. and Tetlow, G. (2009). "What is a public sector pension worth?", Economic Journal, 119: F517-F535.

Disney, R., Emmerson, C. and Wakefield, M. (2008). "Pension Provision and Retirement Saving: Lessons from the United Kingdom", Canadian Public Policy, 34: 155-175.

Disney, R. and Whitehouse, E. (1996). "What are occupational pension plans entitlements worth in Britain?", Economica, 63: 213-238.

Dolton, P. Makepeace, G. and Marcenaro-Gutierrez, O. (2014). "Public Sector Pay in the UK: Quantifying the Impact of the Review Bodies”, Manchester School, 86(6):701-24.

HM Treasury (2011). "Public Service Pensions: Good Pensions that Last”.

Independent Public Service Pension Commission (2011). Final Report.

Ippolito, R.A. (1985). “The labor contract and true economic pension liabilities.” American Economic Review, 75: 1031-1043.

PPI (2015). “The Pension Primer: A Guide to the UK Pension System". PPI report, June 2015. London.

PPI (2013). “The Implications of the Coalition Government's public service pension reforms”, PPI Report, May 2013. London.

PPI (2005). “Occupational Pension Provision in the Public Sector”. PPI report, March 2005. London. 
Thurley, D. (2009). "Local Government Pension Scheme: Rule of 85", House of Common Standard Note 4002. 
Table 1. Changes in pension parameters

\begin{tabular}{|c|c|c|}
\hline NHS & before 2002 & from 2015 \\
\hline Scheme type & Final salary & CARE \\
\hline Accrual rate & $1 / 80$ & $1 / 54$ \\
\hline NPA & 60 & SPA \\
\hline $\begin{array}{l}\text { Revaluation of active } \\
\text { members benefits }\end{array}$ & & $\mathrm{CPI}+1.5 \%$ \\
\hline $\begin{array}{l}\text { Revaluation of } \\
\text { pensions in payment }\end{array}$ & RPI up to April 2011 & $\mathrm{CPI}$ \\
\hline Lump sum & $3 *$ annual pension & $\begin{array}{l}\text { optional in exchange for reduced } \\
\text { pension }\end{array}$ \\
\hline Widow's pension & $50 \%$ of your pension in payment & $33.75 \%$ of the pension in payment \\
\hline $\begin{array}{l}\text { Early retirement - } \\
\text { factor }\end{array}$ & & 0.767 for retirement five years before \\
\hline Civil Service & before 2002 & from 2015 \\
\hline Scheme type & Final salary & CARE \\
\hline Accrual rate & $1 / 80$ & $1 / 43.1$ \\
\hline NPA & 60 & SPA \\
\hline $\begin{array}{l}\text { Revaluation of active } \\
\text { members benefits }\end{array}$ & & $\mathrm{CPI}$ \\
\hline $\begin{array}{l}\text { Revaluation of } \\
\text { pensions in payment }\end{array}$ & RPI up to April 2011 & $\mathrm{CPI}$ \\
\hline Lump sum & 3*annual pension & optional in exchange of reduced pension \\
\hline Widow's pension & $50 \%$ of your pension in payment & $37.5 \%$ of your pension in payment \\
\hline $\begin{array}{l}\text { Early retirement - } \\
\text { factor }\end{array}$ & & 0.769 for retirement five years before \\
\hline Teachers & before 2002 & from 2015 \\
\hline Scheme type & Final salary & CARE \\
\hline Accrual rate & $1 / 80$ & $1 / 57$ \\
\hline NPA & 60 & SPA \\
\hline $\begin{array}{l}\text { Revaluation of active } \\
\text { members benefits }\end{array}$ & & $\mathrm{CPI}+1.6 \%$ \\
\hline $\begin{array}{l}\text { Revaluation of } \\
\text { pensions in payment }\end{array}$ & RPI up to April 2011 & $\mathrm{CPI}$ \\
\hline Lump sum & $3^{*}$ annual pension & $\begin{array}{c}\text { optional in exchange for reduced } \\
\text { pension }\end{array}$ \\
\hline Widow's pension & $50 \%$ of your pension in payment & $37.5 \%$ of your pension in payment \\
\hline $\begin{array}{l}\text { Early retirement - } \\
\text { factor }\end{array}$ & & 0.770 for retirement five years before \\
\hline
\end{tabular}


Table 1. (Continued)

\begin{tabular}{|c|c|c|}
\hline Local government & before 2002 & from 2014 \\
\hline Scheme type & Final salary & CARE \\
\hline Accrual rate & $1 / 80$ & $1 / 49$ \\
\hline NPA & 65 & SPA \\
\hline $\begin{array}{l}\text { Revaluation of active } \\
\text { members benefits }\end{array}$ & & $\mathrm{CPI}$ \\
\hline $\begin{array}{l}\text { Revaluation of pensions } \\
\text { in payment }\end{array}$ & RPI up to April 2011 & $\mathrm{CPI}$ \\
\hline Lump sum & $3 * a n n u a l$ pension & $\begin{array}{l}\text { optional in exchange of reduced } \\
\text { pension }\end{array}$ \\
\hline Widow's pension & $50 \%$ of your pension in payment & $50 \%$ of your pension in payment \\
\hline Early retirement -factor & & Not necessary \\
\hline Police & before 2002 & from 2015 \\
\hline Scheme type & Final salary & CARE \\
\hline Accrual rate & $\begin{array}{c}1 / 60 \text { up to } 20 \text { years }-2 / 60 \text { after } 20 \\
\text { years (capped at } 40 / 60 \text { ) }\end{array}$ & $1 / 55.3$ \\
\hline NPA & 55 & 60 \\
\hline $\begin{array}{l}\text { Revaluation of active } \\
\text { members benefits }\end{array}$ & & $\mathrm{CPI}+1.25 \%$ \\
\hline $\begin{array}{l}\text { Revaluation of pensions } \\
\text { in payment }\end{array}$ & RPI up to April 2011 & $\mathrm{CPI}$ \\
\hline Lump sum & $\begin{array}{c}\text { Optional in exchange for reduced } \\
\text { pension }\end{array}$ & $\begin{array}{c}\text { Optional in exchange of reduced } \\
\text { pension }\end{array}$ \\
\hline Widow's pension & $50 \%$ of your pension in payment & $50 \%$ of your pension in payment \\
\hline Early retirement -factor & & 0.775 for retirement five years before \\
\hline Firefighters & before 2002 & from 2015 \\
\hline Scheme type & Final salary & CARE \\
\hline Accrual rate & $\begin{array}{c}1 / 60 \text { up to } 20 \text { years - } 2 / 60 \text { after } 20 \\
\text { years (capped at } 40 / 60 \text { ) }\end{array}$ & $1 / 59.7$ \\
\hline NPA & 55 & 60 \\
\hline $\begin{array}{l}\text { Revaluation of active } \\
\text { members benefits }\end{array}$ & & Average Earnings \\
\hline $\begin{array}{l}\text { Revaluation of pensions } \\
\text { in payment }\end{array}$ & RPI up to April 2011 & $\mathrm{CPI}$ \\
\hline Lump sum & $\begin{array}{c}\text { Optional in exchange for reduced } \\
\text { pension }\end{array}$ & $\begin{array}{l}\text { Optional in exchange of reduced } \\
\text { pension }\end{array}$ \\
\hline Widow's pension & $50 \%$ of your pension in payment & $50 \%$ of your pension in payment \\
\hline Early retirement -factor & & 0.782 for retirement five years before \\
\hline
\end{tabular}


Table 2. DB pension (dis-) advantage of 2015 scheme at pension age in 2015 prices

\begin{tabular}{lccc}
\hline & DB pension (dis)advantage of 2015 scheme at pension age in 2015 prices \\
& All & A-level or below & Above A-level \\
\hline NHS & 18,900 & 27,400 & -700 \\
Teachers & $\mathrm{n} / \mathrm{a}$ & $\mathrm{n} / \mathrm{a}$ & $-6,700$ \\
Civil Service & 7,600 & 15,900 & $-11,400$ \\
Local Government & 33,800 & 34,800 & 29,200 \\
Police & $-104,400$ & $-78,700$ & $-145,300$ \\
Fire Services & $-129,600$ & $-100,500$ & $-175,900$ \\
\hline Note: About $70 \%$ of employees in each of the occupations hold A-level or below educational qualification (with the exception of \\
teachers).
\end{tabular}


Figure 1. Age earnings profile by education, median

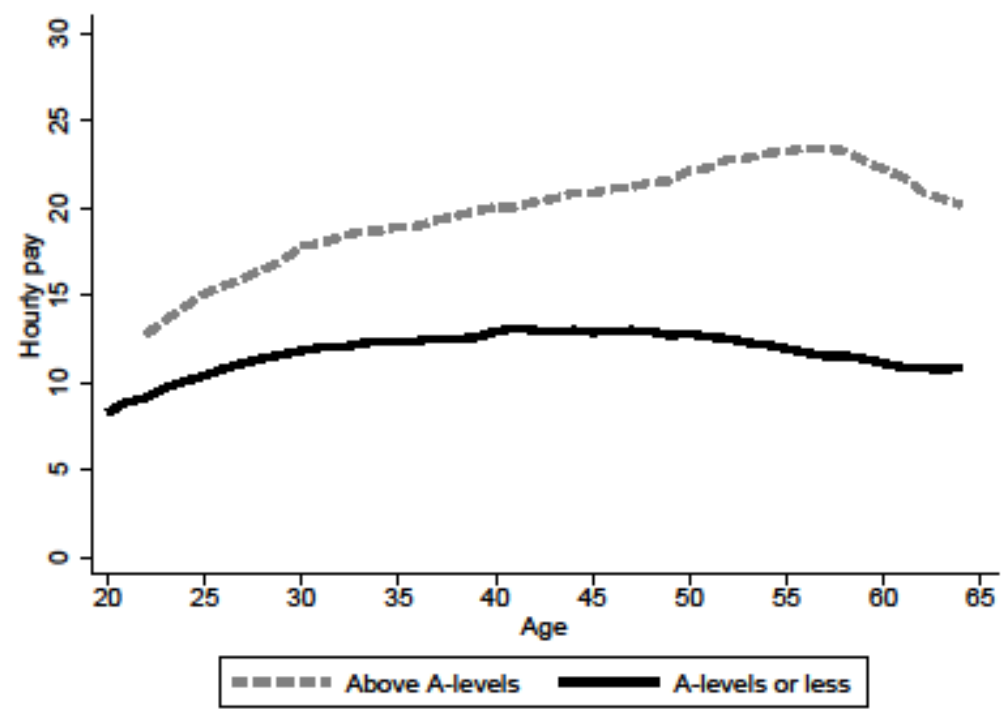

Source: ASHE, 1997-2013. Authors' calculations.

Figure 2. Second step of analysis: DB pension (dis-)advantage of 2015 scheme across public sector pension reforms (education above A-levels)

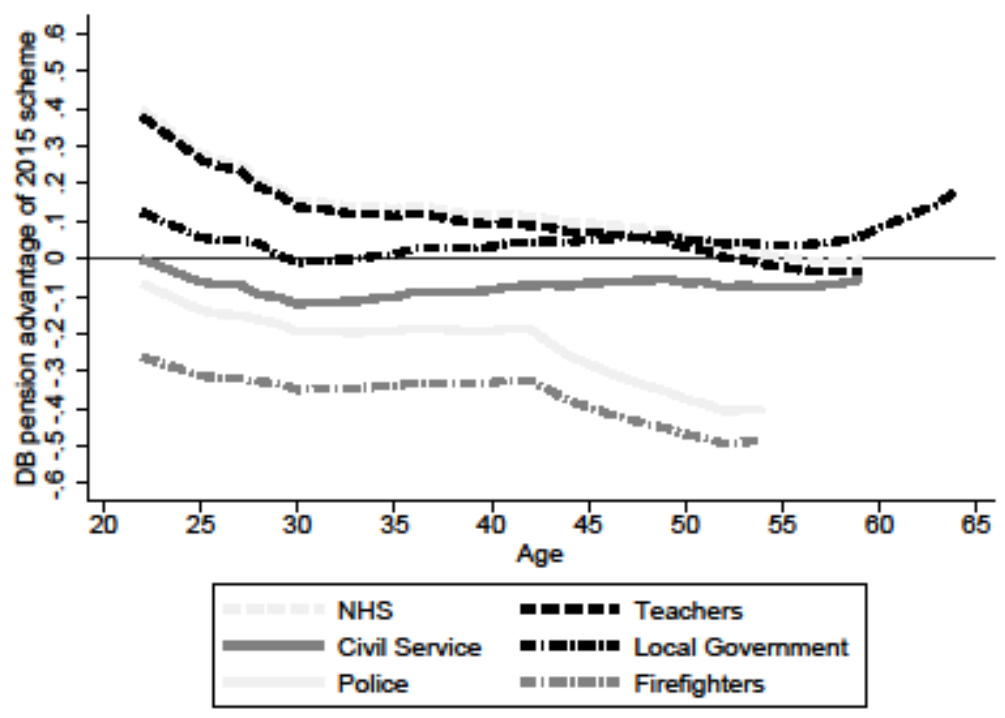

Source: ASHE, 1997-2013. Authors' calculations. 
Figure 3. Second step of analysis: DB pension (dis-)advantage of 2015 scheme across public sector pension reforms (A-levels or below)

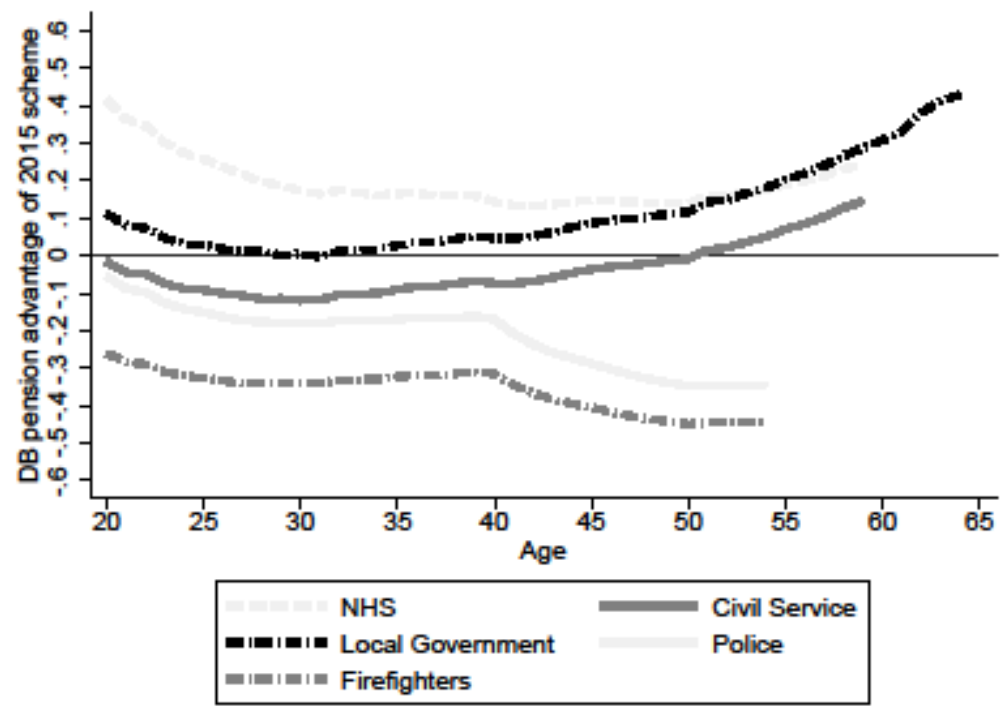

Source: ASHE, 1997-2013. Authors' calculations.

Figure 4. Second step of analysis: Average DB pension (dis-)advantage of 2015 schemes when reaching NPA across public sector pension reforms.

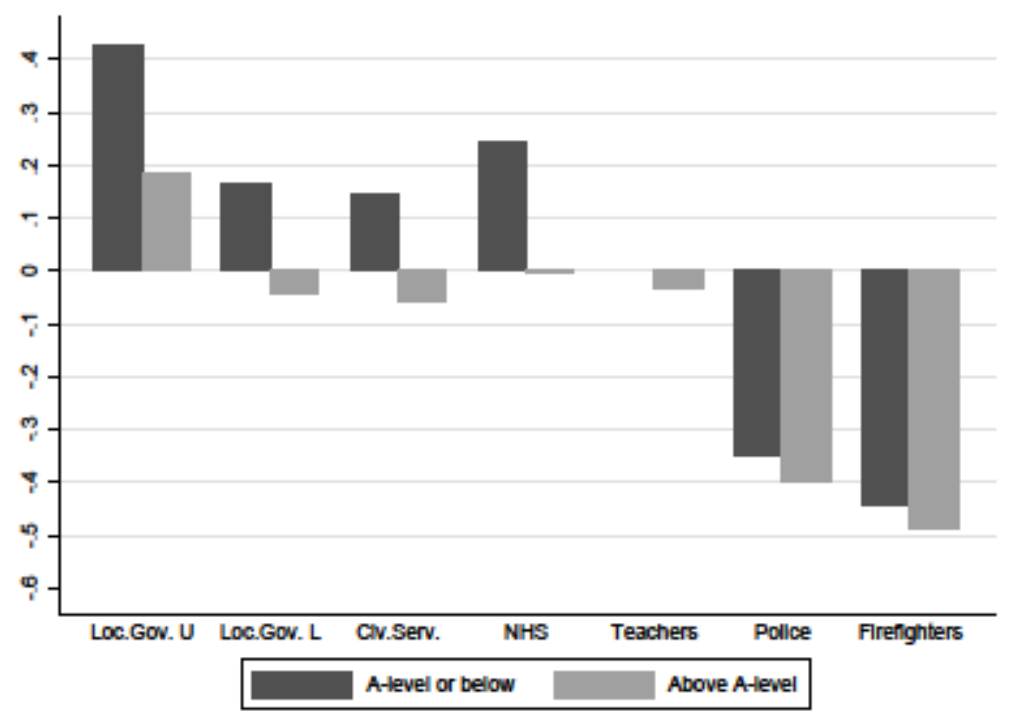

Note. Loc.Gov. U refers to computations ignoring the rule of 85, while Loc.Gov. L takes into account the rule of 85 under the unreformed pension scheme.

Source: ASHE, 1997-2013. Authors' calculations. 


\section{APPENDIX}

\section{Intermediate results}

Figures A1 and A2 report the pension (dis-)advantage of the 2015 pension schemes for our first step of analysis (intermediate results). These results do not take into account the fact that a worker under the old pension scheme has the advantage of retiring 5 years earlier than someone under the 2015 reformed systems (except for the case of Local Government where retirement age is unchanged after the reforms). Figure A1 focuses on educated workers (above Alevels) and Figure A2 on less educated ones (A-level or below). Compared to Figure 2 and 3 the pension dis-(advantage) is shifted upward, showing a smaller decline in pension wealth due the 2015 reforms (except for Local Government where the retirement age remain unaffected by the reform so that the curve does not shift).

Figure A1. First step of analysis: DB pension (dis-)advantage of 2015 scheme across public sector pension reforms (education above A-levels).

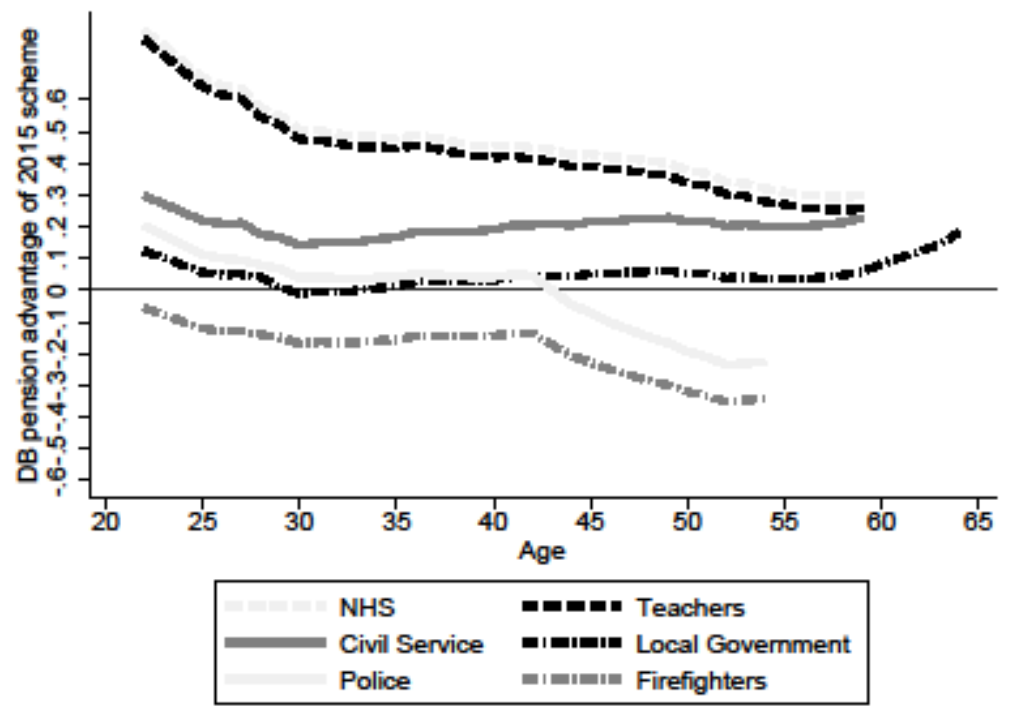

Source: ASHE, 1997-2013. Authors' calculations. 
Figure A2. First step of analysis: DB pension (dis-)advantage of 2015 scheme across public sector pension reforms (A-levels or below)

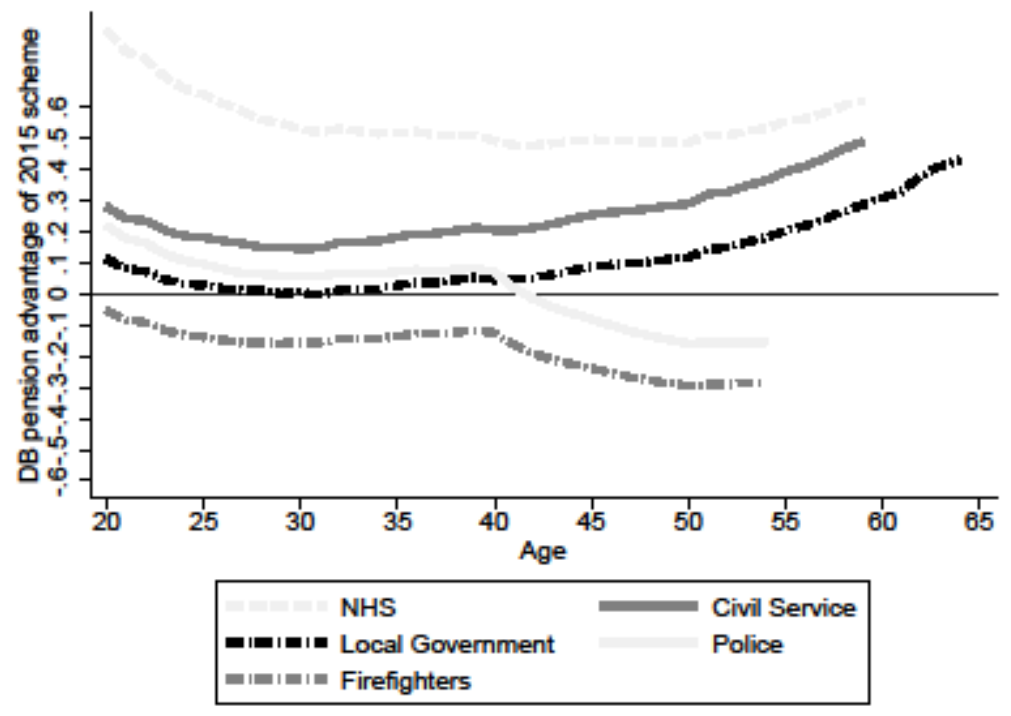

Source: ASHE, 1997-2013. Authors' calculations 